\title{
CHARITY INSTITUTIONS AS NETWORKS OF POWER: HOW ANZIA YEZIERSKA'S CHARACTERS RESIST PHILANTHROPIC SURVEILLANCE
}

\author{
ReBeca E. CAMPOS \\ Complutense University of Madrid \\ rebecampfe@gmail.com
}

\begin{abstract}
At the end of the nineteenth-century, American private institutions took the charge of spreading national values due to the massive wave of eastern European immigration. These institutions, especially charitable organizations, supported the integration of immigrants, however, from a classist perspective. According to the Polish-American author Anzia Yezierska (1885-1970), their apparently inclusive programs actually hindered the fulfilment of the discourse of the American Dream, which is based on the premise of preserving individual differences. By comparing those charitable institutions to Michel Foucault's panoptical prison, this research attempts to demonstrate how the similarities between both structures help understand up to what extent the benefactresses in charge accurately managed to influence the newly arrived immigrants. The hierarchy of power established between them would determine the latter's difficulties to achieve the recognition of their individualities from their intersectional experiences. The alternative to the monitoring network, thus, appears in the act of solidarity, a kind of resistance that allows ghettoized characters to perform their cultural distinctiveness away from Americanization.
\end{abstract}

Keywords: Anzia Yezierska, "My Own People", "The Free Vacation House", charity, power, ghetto, surveillance. 
REBECA E. CAMPOS

\title{
INSTITUCIONES DE LA CARIDAD COMO REDES DE PODER: LA RESISTENCIA DE LOS PERSONAJES DE ANZIA YEZIERSKA ANTE LA VIGILANCIA FILANTRÓPICA
}

\begin{abstract}
RESUMEN. A finales del siglo XIX, una serie de instituciones privadas norteamericanas se encargaron de difundir valores nacionales debido a la oleada masiva de inmigrantes provenientes de Europa del Este. Estas instituciones, especialmente las organizaciones de la caridad, apoyaban la integración de las inmigrantes, sin embargo, desde una perspectiva clasista. Según la autora polaco-americana Anzia Yezierska (1885-1970), sus programas aparentemente inclusivos realmente obstaculizaban la satisfacción del discurso del Sueño Americano, basado en la premisa de preservar las diferencias individuales. Al comparar estas instituciones caritativas con la prisión panóptica de la que Michel Foucault hace referencia, este estudio pretende demostrar cómo las similitudes entre ambas estructuras ayudan a entender hasta qué punto las benefactoras consiguieron eficazmente influir a las inmigrantes recién llegadas. La jerarquía de poder establecida entre ellas determinaría las dificultades de estas últimas para alcanzar el reconocimiento de su individualidad desde su experiencia interseccional. La alternativa a la red de vigilancia, pues, aparece en el acto de solidaridad, un tipo de resistencia que permite a los personajes guetizados representar su distinción cultural fuera del proceso de americanización.
\end{abstract}

Palabras clave: Anzia Yezierska, "My Own People", "The Free Vacation House", caridad, poder, gueto, vigilancia

Received 8 November 2016

Revised version accepted 3 March 2017

\section{INTRODUCTION: PHILANTHROPIC ETHICS}

After the second massive wave of Eastern European immigration to North America at the end of the nineteenth-century, the power relations that kept the high classes on the apex of the social pyramid were strengthened for fear that their cultural values would be jeopardized by the new experiences gathering on the large coastal cities. To avoid this situation, and according to the historical passage rescued by the Polish-American author Anzia Yezierska, several private institutions took the charge of spreading American standards, such as the ones inspired by The Henry Street Settlement, founded by the German-Jewish middle-class nurse Lillian Wald (Hoy 1995: 100), or The Clara De Hirsch Home for Working Girls in New York, where the author temporarily moved into with uplifting expectations. These institutions, also known as "philanthropic homes" (Glenn 1990: 62), facilitated 
the integration of immigrants, however, from a classist perspective since they supported a presumably propitious program to get the social recognition of which the immigrant Jewish women had dreamt.

Like many Eastern European Jewish families at the end of the 19thC looking for a more prosperous and religiously tolerant future in America, Anzia Yezierska's parents also decided to set out on a journey from their native Polish town on the Vistula River towards such prospective expectations. However, her father, committed to the "Old Ways" (Berch 2009: 13), would rather represent for Yezierska the shadow of traditional Judaism with which any Americanizing attempt had to deal eventually. Eager to find expression for the disappointing experience she underwent as a low-class immigrant woman still searching for an opportunity to make herself "for a person" (Yezierska 2003: 172), Yezierska boarded in The Clara de Hirsch Home to qualify for Home Economics and, thus, be able to earn a living and give voice to such early discontent. What she did not expect, though, was that the class hierarchy she intended to overcome was actually the social engine that maintained the philanthropic machinery functioning.

The cultural clash among the different migratory waves was fueled by the stable identity already established by those who had arrived a few decades earlier. In other words, immigrant women had already arrived from the former German Empire between 1840 and 1860, and the newly arrived women from eastern Europe, bringing with them instability and located in the Lower East Side ghetto, had to face their exclusion (Payant 1999: xvii). The philanthropic institutional network, thus, would be promoted by those German-Jewish middle-class women whose main concern was to create easily recognizable archetypes for immigrants to quickly adapt to the new American standards. By participating in such philanthropic projects, the already Americanized women achieve to approach themselves to the public arena so as to enlarge their experiences beyond the private and domestic contexts (Antler 1997: 40). Besides, the settlement workers in charge of facilitating such adaptation, also referred to as benefactresses or friendly visitors in Yezierska's fiction, also spread a specific message: the only way to eradicate that exclusion would be through the formation and participation in the charitable programs intended to foster certain working ethics to avoid laziness and potential begging: "pauperism [...] was [...] a natural illness that marked the poor as a special class of the sick" (Pimpare 2004: 30). Subsequently, "American Jews responded to the social problems created by immigration by engaging in large-scale philanthropic projects [...] to aid the immigrants upon their arrival and to facilitate their rapid assimilation" (Baum 1976: 165). In this way, both the benefactresses and the newly arrived women would be at different privileged stages when the time came to establish their relationships, reaffirming 
the hierarchy of power between both sectors of society. Concerning the lack of public recognition of the ghettoized women, the hierarchy would determine the ineffectiveness of those institutions represented by the first wave immigrants.

At that time, American society was already influenced by discourses whose only purpose was to thoroughly explain how to eradicate certain social decadence that could be apparently felt after women started gaining ground in the public space. In 1873, Edward H. Clarke published a compilation of essays - Sex in Education or a Fair Chance for Girls - where the contemporary educational methods are considered to be the main cause of such decadence. In the book, he states that women's physical specificity must be taken into account when designing learning strategies, so that American individuals can make the most of each instructive experience. By strategically resorting to sexually divided educational methods in schools, his argumentation shaped the idea that women's capability to maintain a successful career could not be equated to that of men's. Since their specific physiological traits required from them special attention and care, women had to be prevented from dealing with their academic requirements as efficiently as their male counterparts did. For this reason, female students in North America were regarded as indirect victims of a common national threat which consisted of their achieving public recognition by deliberately emulating men: "the identical education of sexes [...] will introduce the element of emulation" (1873: 30). Dr. Clarke warns the American audience not to equate women's learning methods with that of men's in an attempt to clarify the reasons why female individuals cannot cope with their domestic duties and, consequently, tend to become mentally disordered: "Later on, when marriage and maternity overtake these girls, they live 'laborious days' in a sense not intended by Milton's line, they bend and break beneath the labor, like loaded grain before a storm, and bear little fruit again. A training that yields this result is neither fair to the girls nor to the race" (1873: 25). Although the accomplishment of domestic tasks, such as caregiving or cleanliness, was directly conferred to women, those belonging to middle- and high classes found escape from the private sphere by occupying both the management and instructor positions within charitable organizations. Furthermore, the spreading of female archetypes was made possible by the benefactresses' influence on the immigrant women's daily lives. When becoming aware of the social recognition that the former group enjoyed, the latter concentrated their efforts on complying with gendered norms in an attempt to achieve the same social status as their instructors.

The teaching of domestic tasks on the part of the charitable institutions was a prolongation of gender roles broadly implemented within American families at the beginning of the twentieth century. The newly arrived women, mostly belonging 
to lower classes, understood domesticity as the only way to get the recognition of their individuality outside the Lower East Side. However, those tasks, as Yezierska describes in the short story "The Free Vacation House" (1920), or in the novel Arrogant Beggar (1927), actually reduced the potential of the individual to the gloom of the private context. In this way, the immigrant's prospective recognition would be exclusively confined to the act of serving an elitist group. By hiring their services in exchange for a small salary, the upper classes successfully maintained class hierarchy, not allowing the Lower East Side immigrants to escape from their social exclusion:

The organized charity movement of the late nineteenth century was funded, staffed, and led not by neutral reformers seeking to improve the lot of the poor, but by business and professional men who sought, often explicitly, to limit charity so that the working classes would be less powerful and more dependent upon their employers. (Pimpare 2004: 80)

Regarding the author's experience as an immigrant, which dated from her arrival in the early 1890s onwards, Delia C. Konzett states that Yezierska herself rejected the charity activities depicted in her stories: "She resented the Americanization programs sponsored by reform-minded Americans of the Progressive Era, particularly the affluent and established Americanized German Jews" (Konzett 1997: 596). Taught to serve through training courses aimed at mastering the usage and layout of the domestic sphere, the Jewish immigrants participated in the charity network and learned their position in North American society from discrimination. Thus, upward mobility and public recognition, aspects which had previously encouraged their trip to the New World, would eventually be devoid of any credibility.

Although the training courses were designed to encourage inclusion in the labor field - "(Anzia Yezierska's) rich patronesses (Sarah Ollesheimer among others from The Clara de Hirsch Home) agreed to pay her tuition as long as she enrolled in a vocational training program in domestic science at Columbia Teachers college (Ginsberg 2016: 93) -, other types of services can be found, such as the routine supervision of each family's resources or the provision of some staple food. Although the supervision was necessary, as these institutions were supported by the altruistic side of the affluent classes and could not afford to provide help without some fixed criteria (Pimpare 2004: 68), it would also determine the ghettoized women's adaptation. As Judith W. Leavitt states, since they lacked any economic stability, the Eastern European immigrants inhabiting this specific context in New York could have put the North American hierarchy of classes at risk: "People with no home or family had been particularly vulnerable to official control, because they did not have the social and physical supports to convince authorities that they could care for themselves and not endanger others" (Leavitt 1995: 158). 
As women, the benefactresses had to confine their social labor within the domestic sphere as well. Belonging to the first wave of immigration from eastern and central Europe, they thought that their social recognition in the public space could be obtained by showing concern for the instruction and care directed towards the less privileged society sectors. As Janet H. Burstein states,

Jewish women were encouraged to withdraw from the marketplace [...] But to aspiring middle-class women America also offered an opportunity to expand their caregiving beyond their families, because philanthropic concern, particularly on a personal level, was considered one of the few activities that might legitimately draw a middle-class woman [...] from her home. (Burstein 1996: 79)

Although Burstein bases her argument on Charlotte Baum, Paula Hyman, and Sonya Michel's research (1976), she also focuses on the tendency of already Americanized women, most of whom described by Yezierska as middle-class and Jewish, towards reproducing stereotyping models of behavior determined by gender. Thus, the fact that the benefactresses acquired social significance when carrying out charitable programs is the result of the accurate execution of a set of imposed gendered norms. In other words, compliance with these norms allowed these women to receive public recognition, which was apparently forbidden in their domestic confinement. However, taking into account the extent to which they were related to caregiving and teaching of domestic tasks, performing female roles actually brought immigrant Jewish women closer to anonymity and servitude and excluded them from every position of relevance beyond socially invisible spaces.

In her novel Arrogant Beggar, published in 1927, Yezierska portrays this situation from the perspective of a young immigrant, Adele Lindner, who, like the author, decides to lodge in a charitable organization to get trained in the field of "domestic sciences." The Home for the Working Girls, inspired by The Clara de Hirsch Home for Working Girls (Ginsberg 2016: 76), represents the network of power that watches over the boarders to both shape an American female type and transform their cultural differences. In this institution, the boarders, constrained by their social class limitations, are intended to assimilate into the American female standard. When Mrs. Hellman, the benefactress in charge, explains to Adele the utility of the courses offered, she reveals the actual classist intention of the discourse with which they describe their social commitment: "It is my hope that this training in domestic science will enable you to become a leader among your people. You can teach them that the joy of living consists on serving others" (Yezierska 2010: 46). In this way, although this type of institutions defined themselves as the most accurate means for immigrant women to transcend their exclusion, the truth, according to the author, is that they actually reinforced the social class hierarchy: "Those with wealth and power who sought to protect their status and enlarge their gains needed, among 
other things, some cohesive rationale, a dominant story that could explain the need for what might seem to be unjust and undemocratic outcomes" (Pimpare 2004: 21). Presenting servitude as the objective to reach, upper classes' strategical altruism eventually contributed to the maintenance of social hierarchy and, therefore, to the impossibility of performing their desired ideal of class equality.

\section{PHILANTHROPIC SURVEILLANCE WITHIN THE PANOPTICAL STRUCTURE}

\subsection{THE "FREE VACATION HOUSE" AS A REFORMING EXPERIENCE}

Given the lack of recognition that the eastern European women faced on the public arena in New York, they initially trusted domesticity as a means of escape from the Lower East Side. However, there is another pressing issue they had to deal with: surveillance. To this respect, the charity institutions depicted by Anzia Yezierska find support in Michel Foucault's theoretical basis on how the institutional networks of power manage to achieve control by turning to panoptical building structures. By referring to Foucault's panoptical theoretical framework, Yezierska's philanthropic organizations can be more accurately approached as they structurally work in a similar way. The author sets out this situation by showing an exhaustive depiction of control exercised upon the characters, which affects most of them throughout her literary production. In one of the short stories, firstly published in 1915 and entitled "The Free Vacation House," the PolishAmerican author demonstrates to what extent the charitable institutions offer these ghettoized women a way out of their poverty; that being the case, she also wonders what they are forced to renounce in order to enjoy their services. In the story, Yezierska decides not to bring to light the name of the main character. In this way, the vulnerability becomes more evident since the character's situation is not reduced to a specific individual, but can be extrapolated to multiple contexts.

The first scene shows the arrival of a visiting teacher to the anonymous main character's tenement flat in response to her apparent lack of attention to her children's school schedule. Realizing the mother's hard living conditions as a consequence of fulfilling both domestic tasks and maternal responsibilities, the woman from the charity recommends her to attend one of their programs in the countryside for two weeks. The institution's purpose is advertised as an altruistic strategy by hosting women whose limitations destabilize their duties as mothers and householders: "I know of a nice country place for mothers and children that will not cost you anything. It is free" (Yezierska 2010: 43). Furthermore, the benefactress's unexpected visit denotes both a lack of intimacy, which can be considered as a typical high class privilege, and the existence of a monitoring network present throughout the New York Jewish ghetto. 
Once the case is reported, a supervisor is sent the following day to coordinate the inclusion of the young girl in the program that the institution - "Social Betterment Society" - endorses. The intrusion of higher-class characters in the urban low-class context under the premise of ensuring stability enhances the young woman's vulnerability since she becomes the target of a strategically paternalistic purpose. The main character's experience becomes a subject of study monitored by figures such as the friendly visitor, whose unexpected presence does not take into account the ghettoized women's will. This is depicted in the story, when the young girl states, "The lady take herself a seat, and then takes out a big black book from her satchel. Then she begins to question me. What is my first name? How old I am? From where come I? How long I'm already in this country?" (Yezierska 2010: 44) In addition, the fact that these charitable organizations had a limited income at their disposal, mostly coming from private benefactors, such as the wealthy banker Henry Ollesheimer (Ginsberg 2016: 76), implies the need to discriminate some situations in favor of those more propitious for receiving their services: "Charity organization societies urged that relief be administered privately to reduce the power of patronage in relief giving and to lodge its administration in institutions that would better discriminate than government or the churches between the 'worthy' and 'unworthy' poor" (Pimpare 2004: 48). Besides, to manage their duties, it became essential to record every candidate's situation in order to carry out an accurate selection by following previously fixed criteria. In the story, this is noted as, "We must make a record of all the applicants, and investigate each case [...] There are so many who apply to the charities, we can only help those who are most worthy" (Yezierska 2010: 44). A hierarchy is established when it is time to select which candidate fits best, which determines behavior insomuch as the ghettoized women feel compelled to shape their experiences according to the institutions' requirements. Such influence, though not precisely shown in this short story, appears in another work entitled "My Own People," which is discussed further in the following section.

For the young girl, the program designed by the Social Betterment Society means the acceptance of her social invisibility and the assumption that she is to participate in a rescue plan for which only the beggars are apparently considered. The young woman states, "Ain't the charities those who help the beggars out? I ain't no beggar. I'm not asking for no charity" (44). Rejecting the services offered by this type of organizations is a recurrent theme along Yezierska's fiction. The rejection takes place once the ghettoized characters unveil the charity's actual purpose, which widens, rather than narrowing, the cultural chasm between eastern European women and those already settled decades before. Despite her initial refusal, though, the main character finally accepts their help so she can dissociate herself for a short period of time from the domestic duties with which she cannot cope. After a second phase of 
interrogation, during which the same questions are formulated with the aggravation of being asked before the other female candidates, the benefactresses lead them to a health examination room: "A man doctor with a nurse comes in, and tells us to form a line, to be examined [...] From the way he was afraid to touch us or come near us, he made us feel like we had some catching sickness that he was trying not to get on him" (46). This scene is reminiscent of Mary Antin's experience depicted in her autobiography, The Promised Land, published in 1912. She and her family were compelled to pass through a medical examination when they reached the frontier between the former Russian and German empires to check whether they could put at risk the public health in the territories they had to travel across: "At Versbolovo, the last station on the Russian side, we met the first of our troubles. A German physician and several gendarmes boarded the train and put us through a searching examination as to our health, destination, and financial resources" (Antin 1997: 135). The Jewish families belonging to the former Russian Empire had to fulfill certain hygiene and health expectations influenced by the discourses of the higher classes, scared of seeing their perdurability destabilized. Likewise, the main character in "The Free Vacation House" is thoroughly examined to check if she is suitable enough to receive the charitable services. Both medical examinations, thus, are intended to classify and judge the individual according to classist and discriminatory interests.

In Yezierska's works, the strategy followed by the charitable institutions deals with the survival of the predominant values of the elitist society (North American, in this context), which decides what aspects should be taken into account regarding the inclusion of individuals with different cultural backgrounds in the public space they supervise. Moreover, the intrusion of these institutions in the ghettoized women's lifestyles encourages, as Yezierska displays, their stay on the margins and not their actual inclusion. The discourse that judges each individual's health standards at the European borders and the one which allows the benefactresses to judge the individual's level of poverty have been both designed on the basis of social discrimination. In fact, the latter is not addressed to get access in the public space. Rather, it concretely confines women within the urban ghetto they have purposely been located in.

Once the anonymous protagonist arrives at the place in the countryside, she connects the benefactresses' surveillance with her feeling imprisoned inside categorization: "When she already got through asking us out everything, she gave to each of us a tag with our name written on it. She told us to tie the tag on our hand. Then like tagged horses at a horse sale in the street, they marched us into the dining-room" (Yezierska 2010: 47). Being labeled and classified in minute detail clearly implies the character's dehumanization process as the type of social network the benefactresses intend to establish; the boarders themselves feel forced to be 
defined by a serial difference - that is to say, their personal details and economic status. In addition, the young girls must obey certain norms shaped to understand individual behavior in terms of collectivity; subsequently, their individuality is called into question and constantly monitored, being also restrained throughout the period when the services are offered. In this respect, it is relevant to point out what Michel Foucault states in his analysis of the mechanisms of control, especially those associated with what is currently known as a prison. Foucault refers to the need of institutionalized systems of registering and taking notes on those individual conditions that have originated crimes. As Foucault argues, "A whole corpus of individualizing knowledge was being organized [...]. The prison functions in this as an apparatus of knowledge" (1977: 126). In the same way, the Social Betterment Society, though a private institution, also appears as an "apparatus of knowledge" insomuch as it records each candidate's profile and establishes standards of poverty upon which it judges the boarders' suitability. Although the French philosopher focuses on the public organizations supported by a governmental supervision, the charitable institutions to which Yezierska refers can be understood as equally productive in terms of structural providers of information. Due to their interest in making the American female archetypes last, these institutions have the mission of transforming the individual, something reminiscent of the corrective pretensions of the prison described by Foucault. In this way, the three interrogations they have to go through take part in the structural framework of power with the only aim of surveilling the correct compliance of the norms upon which it has been built.

As soon as the ghettoized Jewish women arrive at the countryside house, one of the benefactresses makes them aware of the rules that must be fulfilled during their stay, again emphasizing the indoctrinating nature of the institution: "When she got through with the rules, I was wondering which side of the house I was to walk on. At every step was some rule what said don't move here, and don't go there, don't stand there, and don't sit there" (Yezierska 2010: 48). In spite of this, after experiencing how the facilities show the cleanliness and hygiene typical of the higher classes, the girl apparently forgets the strict obedience she denounced moments before: "I soon forgot again all my troubles" (47). Well aware of the influence the display of cleanliness has among the immigrant girls, the benefactresses take advantage of such longing in order to spread high-class archetypes. By compelling the ghettoized women to keep the facilities clean, they are at the same time using that workforce to maintain American standards of hygiene, being the only beneficiaries of the outcome. In this way, the main character witnesses how the power relationships are established between a group of low-class women and those belonging to a more well-to-do sector, and how these local relationships indirectly help to globally maintain class differences: 
On every few days there came to the house swell ladies in automobiles. It was for them that the front from the house had to be always perfect. For them was all the beautiful smelling flowers. For them the front porch, the front sitting-room, and the easy stairs with the carpet on it. (48)

Therefore, in contrast to the boarder's poverty, the benefactresses enjoy a set of privileges that their status as middle-class women provides them with. Joyce Antler brings to light the consequences of these Jewish immigrants taking part in the highclass dynamics: when they "Leave the poverty and despair of the ghetto behind them, this triumph is mitigated by the loneliness they find" (Davidman 1994: 197).

The external part of the house remains under uninterrupted surveillance so as to guarantee cleanliness and turn such standards of hygiene into a pleasant experience. By making sure that the exterior space does not incur any damage, the directors can enjoy the visual pleasure perceived when looking at it. Likewise, the emerging female stereotypes spread throughout North American society at the time were also intended to provoke satisfaction and pleasure in potential recipients or observers. Unable to purchase the outcome of their effort, the boarders are compelled to produce visual pleasure indirectly participating in the American consumption market strategies: "To guide that purchasing stores worked assiduously to make women want to be the beautiful, stilled, highly decorated creations they saw in the windows there" (Adams 2012: 67). In the same way as the products displayed in the shop windows along large New York avenues and the female archetypes created to satisfy consumption needs, the external part of the charity building also participates in a marketable process. As a result, the building's external part becomes a symbolic consumer good that, though it is not put on sale under a monetary transaction, is displayed in a way that raises pleasure in the observer. Once its value is perceived and acknowledged by the elitist group, the purpose of its exposition is eventually fulfilled - that is to say, it is acquired and consumed. To make this process of acquisition last, the immigrant women are dehumanized and subjected to specific rules that aim to prevent them from trespassing the limits of their conditioned identity as Jewish, immigrant, low-class women:

Always when the rich ladies came the fat lady, what was the boss from the vacation house, showed off to them the front. Then she took them over to the back to look on us, where we was sitting together, on long wooden benches, like prisoners. (Yezierska 2010: 48)

As the New York Jewish ghetto of that period can be understood as a space where the individuals whom the dominant classes despised were crowded together, the backyard of the depicted charity building also represents a border of exclusion. Given their cultural differences and lack of social status in comparison 
with the normalized identities of the benefactresses, the ghettoized individuals are once more forced to experience the public space in the background.

Alienated and devoid of the attention they expected to receive, the Jewish boarders face exclusion from a very subtle perspective. Having their basic needs covered offsets the servitude of the tasks required against the distance taken away from the ghettoized context from which they come, turning their toiling into something less explicit: "Life at the vacation house is an accumulation of rules that imprison the poor mother in more ways than life in the tenements ever could" (Billeter 2011: 63). The main character eventually reveals and denounces the humiliation she has gone through by alluding to all ghettoized women enduring that experience. Her identification with the rest of the boarders shows the character's need of taking distance from American strategies of social integration, which Yezierska steadily demonstrates in this story:

If the best part of the house what is comfortable is made up for a show for visitors, why ain't they keeping the whole business for a show for visitors? For why do they have to fool in worn-out mothers, to make them think they'll give them a rest? Do they need the worn-out mothers as part of the show? I guess that is it, already. (Yezierska 2010: 49)

As it has been previously stated, the constant surveillance upon the individuals belonging to a specific community enhances the maintenance of controlling structures to ensure submissiveness towards the standard. In this context, the benefactresses' main concern is not only the instruction of American behavioral codes to newly arrived immigrants, but also the maintenance of their social status. Thus, to support this situation, it becomes necessary for them to rely on the female boarders' workforce and commitment.

With the purpose of transforming the behavior that has led the female boarders to such an apparently unstable situation, the Social Betterment Society focuses on classifying ghettoized women's profiles to prevent any upcoming signs of potential rebellion. As a result, they would avoid the rise of a collective denouncement that may destabilize the social hierarchy. It is worth noting Foucault's statement regarding the corrective nature of the reformatories in opposition to the corrective sentences applied in prisons, since the charity network also intends to transform the individual's behavior: "Individual correction must, therefore, assure the process of redefining the individual as subject of law, through the reinforcement of the systems of signs and representations that they circulate" (1977: 128).

Taking the Social Betterment Society as a reformatory structure, and following Foucault's argument, it can be stated that the low-class female boarders, whose crime is the failure to fulfill their role as mothers when simultaneously attempting to cope with domestic tasks, eventually rectify their rebellious attitude and gladly 
go back to their ghettoized routine. When the main character expresses her happiness on returning to the Lower East Side, which previously she despised, she is actually confirming the extent to which these institutions influence their candidates and how their methods are accurately enough conducted to transform an individual's behavior:

How good it was feeling for me to be able to move around my own house, like I pleased. I was always kicking that my rooms was small and narrow, but now my small rooms seemed to grow so bug like the park [...] All these ugly thinks was grand in my eyes. Even the high brick walls all around made me feel like a bird what just jumped out from a cage. (Yezierska 2010: 49)

In addition, when Foucault refers to "representations," what he attempts to show is these institutions' need of publicly spreading the representations of the sentence to generate a kind of collective knowledge that would eventually prevent lower classes from repeating rebellious acts.

The Social Betterment Society, therefore, is characterized by two main aspects, directly connected to Foucault's panoptical prison. On one side, its reformatory purpose, which persuades the individual who commits an offense not to make it happen again. On the other side, its use of disciplinary techniques, which turns the individual into a passive observer of their dehumanization, referred to as "forms of coercion, schemata of constraint, applied and repeated. Exercises, not signs: time-tables, compulsory movements, regular activities, solitary meditation, work in common, silence, application, respect, good habits" (Foucault 1977: 128). When the young girl denounces either the abuse coming from the large number of prohibitions or the strict rules to which they have to submit themselves, what she actually does is report a network of power minutely designed to alienate the ghettoized low-class Jewish women. By taming their behavior, the Social Betterment Society corrects their temperamental deviations and prevents them from future rebellions.

According to the definition with which Foucault refers to those individuals serving a life sentence as their corrective punishment - "the obedient subject, the individual subjected to habits, rules, orders, an authority that is exercised continually around him and upon him, and which he must allow to function automatically in him" (1977: 129) -, the immigrant woman portrayed by Yezierska also experiences her own routine subjected to the whims of others. Obedience would be one of the key aspects when it comes to understand these charitable institutions' functioning, since the fact that the female boarders consent to their dehumanization and obey the orders they are given allows the class hierarchy to keep reproducing inequality. The domination of some groups by others is based on the assumption that social determinism lies behind the accuracy with which the charitable power structure 
accomplishes its task. Thomas Kelley makes reference to how Andrew Carnegie and John D. Rockefeller, early twentieth-century American magnates and philanthropists, supported such hierarchical structure on moral grounds: "Steeped in Social Darwinism, they believed it was a waste of time to defy the evolutionary process by supporting the weaker of the species, those who in earlier generations would have been referred to as the 'undeserving,' 'idle,' or 'sturdy' poor" (2005: 2455). As long as Yezierska's characters continue submitting themselves to the domestic tasks, attributed to them because of their being women and poor, that model of domination will keep being reproduced. Within this social circle of interdependence, where some members struggle to maintain the class hierarchy, the Americanization process is continually producing new discourses and taking different shapes to be acquired as a lifestyle. Therefore, the public integration that the ghettoized Jewish women wish to achieve cannot be attained through the act of servitude, which is euphemistically hidden under the accomplishment of the domestic science courses.

The Social Betterment Society, in this way, delivers an attractive discourse that proposes the newly-arrived immigrants a temporary solution to the possible inconveniences that their life in the ghetto may suppose. However, as Susan A. Glenn stated regarding the domestic tasks as a way of escape from exclusion, the servitude appears as a paternalistic means that imprisons the ghettoized women within their social class cell:

Whatever material comforts and security were afforded to domestics, the benefits scarcely compensated for the humiliation associated with servitude. Not only did it imply a loss of independence and an acknowledgement of inferiority, but it meant cleaning, sweeping, laundering, and other tasks labeled "dirty work." (1990: 16)

The short story "The Free Vacation House" shows how, after experiencing servitude while at the countryside, the main character finally values the private space of the Lower East Side and adjusts herself to the lifestyle she has been allocated, reinforcing the corrective nature of such philanthropic American institutions.

\section{2. "MY OWN PEOPLE” AS AN EXAMPLE OF EFFECTIVE SURVEILLANCE}

Along Anzia Yezierska's fiction, topics dealing with controlling structures of power within the urban context of America are recurrently found. However, the author also offers an alternative to take distance from that strategically classist structure. To exemplify this alternative, it is relevant to mention another short story, "My Own People," which belongs to the same collection, Hungry Hearts (1920). In this story, Yezierska describes how the omnipresence of the charitable institutions' surveillance comes into conflict with the solidarity associated with the Jewish background of Lower East Side inhabitants. 
Sophie Sapinsky, a young girl who aspires to become a writer, boards in a room that Hanneh Breineh, a Jewish mother and peddler, has inside her tenement flat. In the same way as the anonymous mother in "The Free Vacation House," Hanneh complains about the impossibility of fulfilling her duties as mother, finding relief in expressing her despair before her new boarder: "The president from America should only come to my bitter heart [...] Let him try to feed his children on the money the charities give me and we'd see if he wouldn't better send his littlest ones to the shop better than to let them starve before his eyes" (Yezierska 2010: 102). Her statement discloses both the constant surveillance coming from the charitable institutions and the insufficient quantity of provisions that ghettoized women receive, which prevents Hanneh from raising her social status and compels her to depend on street trading.

While in "The Free Vacation House" the alternative offered means the participation of ghettoized Jewish women in the corrective programs sponsored by the Social Betterment Society, here Yezierska shows a way of escape that does not necessarily pass through charity, but takes place thanks to the generous gesture of Shmendrik, a Lower East Side inhabitant that lives next to Hanneh's tenement flat. After an acquaintance has given him a bundle of food, he decides to share it with Hanneh and her children. While the solidarity act is being carried out, though, a benefactress suddenly appears, which symbolically confirms the vulnerability of ghettoized inhabitants in terms of privacy - "Unannounced, a woman entered - the "friendly visitor" of the charities. Her look of awful amazement swept the groups of merrymakers [...] 'I came to my monthly visit - evidently I'm not needed"' (105) - . The intrusion of the friendly visitor in the private spaces the characters dwell is a direct consequence of the invisible surveillance to which these Jewish women are exposed. The fewer their means, the larger the extension of knowledge needed around their experiences becomes. A science of knowledge is therefore produced, which feeds on an unforeseeable surveillance: "Most of the COS (Charity Organization Societies) reformers implemented a charity that, whatever its intent, was in effect an attempt to monitor and change the behavior of their poor petitioners" (Pimpare 2004: 70).

The characters, forced to remain unaware of the time when the surveillance starts, feel the pressure of the power hierarchy that persuades them not to reject the behavioral stereotypes associated with their social status, such as enjoying Shmendrik's cake, which they are not presumably able to afford.

Taken from Jeremy Bentham's panoptical construction (Bentham 1791), the French philosopher's redefinition of the contemporary prison and its effects points out the accuracy with which surveillance takes over rebellion by inducing "in the inmate a state of conscious and permanent visibility that assures the automatic functioning of power" (Foucault 1977: 201). The sudden appearance of the benefactresses in the ghettoized tenement flat acts as a warning that compels their inhabitants 
not to surpass what they are socially expected not to. Otherwise, it would imply expulsion from the charitable programs, thus increasing their vulnerability: "One of the principal functions of friendly visitors was to recommend whether a family should receive assistance, and in what form, which was clear to those visited: among their challenges, then, was to at least appear to be comporting with the desired behavior of their visitor, since fewer than one in three applicants was eventually deemed worthy of relief" (Pimpare 2004: 70). In the same way as the prisoner within the panoptical structure pays for his crime by being constantly exposed before one or more overseers, whose activity is unknown by the prisoner, so are the ghettoized women receiving charitable aid, as if they were serving a sentence for having committed a crime. Thus, the crime for which these characters are forced to constrain their experience under the surveillance of such institutions implies two premises.

On one side, the crime would be related to denouncing or complaining about a situation that is no longer bearable, as is the case of the anonymous mother in "The Free Vacation House." To reform rebellious behaviors, these New York charitable institutions recreate prison policies inside a shelter with the purpose of persuading the boarders to leave their will of change and discomfort behind. The servitude that the female characters have to endure inside those shelters is such that they prefer to go back to the Lower East Side, which confirms the efficiency of the programs in pursuit of fulfilling Americanness by hindering upward immobility.

On the other side, the wish to achieve Americanization by lacking the means to maintain what would be the new identity also determines their being steadily watched over, as if they have, once more, committed a crime. In order to avoid the punishment of constant surveillance, they feel compelled to take part in that process. By completely Americanizing themselves and not displaying any remaining feature from their cultural heritage, they supposedly get rid of their oppression. To ease the Americanization the charitable institutions suggest the participation in the "domestic sciences" courses. Places such as the Home for the Working Girls in the novel Arrogant Beggar, or the Manning Settlement House in Salome of the Tenements, teach immigrant women domestic tasks as the fastest way to gain access to the labor dynamics of the city and, thus, to the recognition of their individuality in the public space. According to Yezierska, however, these institutions intentionally teach them how to become high-class servants instead, which leads them back to the Lower East Side once they have realized of the deception. An accurate performance of the Americanized identity would therefore allow them to be released from the influence of the charity network insomuch as they could enjoy economic autonomy, though that does not mean to elevate social status. 
The outcome resulting from both possibilities confirms the efficacy of the charitable programs insomuch as they strategically cause the characters' return to the ghettoized context from which they have attempted to escape.

On the whole, the prison as a panoptical building and the strategies carried out by the charitable institutions here depicted need surveillance to maintain their functioning. In Foucault's words, "any panoptic institution, even if it is as rigorously closed as a penitentiary, may without difficulty be subjected to such irregular and constant inspections" (1977: 207). Both the criminals and the boarders find themselves under supervision of an authorized group that is at the same time observed and analyzed by its own members. Understanding Hanneh Breineh's tenement flat as a place where certain discipline has to be obeyed and whose access is free to be unexpectedly supervised, it symbolically functions as a cell belonging to a panoptical structure, such as that described by Foucault.

The social invisibility of the ghettoized Jewish families is understood as a consequence of their not being able to properly Americanize, which would imply both the acceptance of the consumption market values and the rejection of the Jewish tradition. In other words, their exclusion represents the sentence to which they have been condemned. Likewise, the friendly visitors symbolize the guards that monitor the fulfilment of the sentence inside the prison by registering the low-class experiences in favor of a scientifically sociological interest. As long as surveillance and expulsion from society are the unavoidable consequences of committing a crime, then the same structural punishment manages both Foucault's prison and Yezierska's institutions.

Therefore, the sudden arrival of a friendly visitor to Hanneh Breineh's flat when an infraction is being committed reveals the incompatibility of her neighbor's generosity with the institution's regulations. The benefactress's departure with the pretext of reporting about what has just happened causes Hanneh to give expression to her despair once again, denouncing their lack of understanding: "Will we get no more dry bread from the charities because once we ate cake?" (Yezierska 2010: 105) For her disobedience, Hanneh gets expelled from the charitable program, a kind of punishment that would accentuate the one already sentenced for not getting involved in the American labor dynamics: poverty. This corroborates the ghettoized character's need of fulfilling expectations related to her social class context. In this regard, Elizabeth Ewen makes reference to the labor carried out by Mabel Kittredge, born in North America and dedicated to teach cleanliness and hygiene archetypes performed by middle and high-class women. Her argument explicitly shows how the charitable institutions in charge of spreading the "domestic sciences" followed a specific educational strategy, 
REBECA E. CAMPOS

which would consist of teaching ghettoized women to Americanize their home without that implying an increase of their incomes:

\begin{abstract}
Mabel Kittredge, a leader of the scientific housekeeping movement, was upset about the furnishings that immigrant women used in their fight against the ugliness of tenement living [...] Kittredge wanted to tear down all the home decorations in immigrant households and replace them with 'scientific knowledge regarding food, air, sun, and cleanliness.' To do this, she established what she called 'model tenement apartments,' decorated in austere style along the lines of a hospital room where immigrant women were given demonstrations of clean, uncluttered 'scientific' living. (1985: 157)
\end{abstract}

This extract is relevant to understand the reasons why Hanneh eventually reveals the fake nature of those training courses to provide Jewish women from the Lower East Side with the necessary tools to escape from their exclusion: "She's a 'friendly visitor!' She learns us how to cook cornmeal. By pictures and lectures she shows us how the poor people should live without meat, without milk, without butter, and without eggs. Always it's on the end of my tongue to ask her, 'You learned us to do without so much, why can't you yet learn us how to eat without eating?"' (Yezierska 2010: 105) Described as such, teaching to imitate high-class dishes when lacking the means to cook them supports the acceptance of the social class differences for two main reasons. Firstly, these women are taught to reduce the time spent accomplishing the domestic tasks so they can gain enough confidence to apply what they have learnt when working as servants for the higher classes. And secondly, they are also taught to reduce living expenses and make the most of low incomes so that they are able to maintain a more comfortable life and, thus, a less rebellious attitude.

When getting in contact with the benefactresses, friendly visitors and the boarding directors, Yezierska's main characters become aware of their vulnerability after witnessing their being treated as prisoners. In this way, the class differences are constantly perceived since they become more and more evident once both female groups share the same spaces: "Charity ladies? - gladness?' [...] 'For poor people is only cornmeal. Ten cents a day" (105). Furthermore, the subsequent arrival of some benefactresses at Hanneh's flat inside an ostentatious vehicle while wearing expensive clothes points out again the different lifestyles between both social classes: "The soft sound of a limousine purred through the area grating and two well-fed figures in seal-skin coats, led by the 'friendly visitor,' appeared at the door" (106). The exam to which these women are submitted inside their home demonstrates the defenselessness they suffer in comparison with the power exercised by institutions such as the Social Betterment Society. As part of its committee, Mr. Bernstein, headmaster of the center and responsible for carrying out the investigation, thoroughly scrutinizes Shmendrik's letters so as to check the 
times that the infraction may have been committed. After confirming the recurrence of the disobedience, he charges the ghettoized character with reporting them to the institution: "You are charged with intent to deceive and obtain assistance by dishonest means" (106). Using the same discursive strategies with which the criminal is charged at the law court, the headmaster, accompanied by a friendly visitor in charge of recording everything, participates in the structure of power to which Foucault refers in his writings.

In this sense, the French philosopher states that those individuals submitted to the same set of regulations tend to unintentionally surveille each other's actions as part of their duties, turning themselves into their own prosecutors: "He who is subjected to a field of visibility, and who knows it, assumes responsibility for the constraints of power [...] he becomes the principle of his own subjection" (1977: 203). By making reference to the reproduction of the "coercions of power," he leaves little room for the criminals to generate any kind of resistance due to their not being aware of those moments when the system of surveillance turns itself vulnerable-that is to say, those moments in which criminals can perform a transgression without being observed. In contrast, inside the private context of the Lower East Side that transgression would be represented in Shmendrik's act of solidarity when sharing the bundle of food and sweets he was given with Hanneh's family. This act symbolically becomes a resistance within the surveillance network carried out by the Social Betterment Society. Given the fact that this resistance does not come from any Americanizing strategy, the institutional justice exercises its punishment by preventing them from receiving any charitable aid, depending only on the community's supportive ties. By establishing solidarity as an alternative different from the strategies proposed by those institutions, the ghettoized Jewish neighborhood is able to relieve its inhabitants from the burden of exclusion.

\section{SOLIDARITY AS AN ALTERNATIVE TO CHARITY}

Although early twentieth-century American charitable institutions made use of different types of strategies, such as the surveillance and the training courses on domestic sciences, to facilitate the adaptation of Eastern European immigrants, the power they exercised upon lower classes urged the creation of different alternatives regarding urban survival. Owing to their disciplinary habits, along with their corrective programs, these institutions share some features with Foucault's panoptical structure. As they both exercise punishment towards certain individuals that do not comply with what they are socially expected to, they have to guarantee that those individuals receive an accurate treatment so they do not repeat the offense once they retake their previous routines. Therefore, the strategies spread 
by the charity network are built upon paternalistic foundations and influenced by the female stereotypes of the period, which were determined by the consumption market rules and the classist discourses that attempted to exclusively confine the lower class's experiences within the privacy and invisibility of the urban ghettos.

Anzia Yezierska provides her literary production with the sufficient amount of experiences so as to be able to analyze the different strategies that American philanthropic institutions put into practice to build a prototype around which the New York higher classes perpetuated their status on behalf of accurate integration. By considering solidarity between the ghettoized neighbors of the Lower East Side as a resistance, the author displays an alternative different from the servant-like model established by the Settlement projects. In this regard, when Katherine Stubbs refers to Jewish tradition, she highlights the importance of the tsdokeh, originally Hebrew, which defines what in the western societies is understood as "charity", but in terms of social justice (Yezierska 2004: xxix). Both the one who begs and the other who gives deserve the same value, being the latter directly dependent upon the former to win the heavenly grace. Therefore, the resistance Shmendrik carries out in "My Own People" may be directly influenced by that Jewish practice, in which the individual gets voluntarily involved, following Lori Merish's definition, in "a communitarian model of anonymous and reciprocal giving" (2012: 222). Although related to giving to the poor, tsdokeh also exemplifies the solidarity with which these low-class ghettoized characters understand their social commitment, considering privileges as commodities they mostly enjoy by sharing with others.

In another Yezierska's major work, Arrogant Beggar (first published in 1927), Adele, a former boarder in the New York settlement "Home for the Working Girls", also experiences solidarity when she encounters with Muhmenkeh, an old Jewish woman that offers her home to the young girl as a temporary shelter without asking anything in return. After discovering that Muhmenkeh spent her savings in Adele's recovery, the young girl realizes that the charitable network previously promoted by the American settlement does not solve the immigrant's lack of economic resources. Besides, according to Merish' argumentation, the need of individual recognition typical of philanthropic institutions - as Mrs. Hellman embodies when being advertised in the American papers as the founder of the Settlement and a role model of benevolence (Yezierska 2004) - may conflict with the Hebrew concept since this takes place from an altruistic urge based on an anonymous generosity: "it is they who name the home 'Hellman Home' after its founder, a clear contrast to the shtetl tradition of $t$ sdokeh, a communitarian model of anonymous and reciprocal giving" (2012, 222). As well as Hanneh in "My Own People" denounces the friendly visitors' paternalistic strategies, Muhmenkeh also prevents her streetpeddling profession from being controlled by the Hellman's philanthropic discourse. 
When Arthur intends to give Muhmenkeh an amount of money that clearly exceeds the one she proposed in exchange of her stock, the old Jewish woman rejects his offer, which undermines the American act of charity in favor of the solidarity her actions represent: "No, Mister. Your heart is good. But Gott sei dank, I got yet my hands and feet to earn me my every cent" (Yezierska 2004: 110).

According to Yezierska's fictional works, therefore, while the discourses supporting charity enhance the individual's loss of agency as a consequence of complying with the philanthropic agenda, the acts of solidarity she depicts serve as a means through which her characters are more likely to find personal fulfilment in a place where the new standard of living seemingly undermines their earlier future prospects.

\section{REFERENCES}

Adams, Katherine H., Michael L. Keene and Jennifer C. Koella, eds. 2012. Seeing the American Woman, 1880-1920: The Social Impact of the Visual Media Explosion. North Carolina: McFarland \& Co.

Antin, Mary. 1997 (1912). The Promised Land, with an introduction by Werner Sollors. New York: Penguin Books.

Antler, Joyce. 1994. "Sleeping with the other: The Problem of Gender in AmericanJewish Literature". In Feminist Perspectives on Jewish Studies, edited by Lynn Davidman and Shelly Tenenbaum. New Haven, CT: Yale University Press. 191-223.

Baum, Charlotte, Paula Hyman and Sonya Michel, eds. 1976. The Jewish woman in America. New York: Dial Press.

Bentham, Jeremy. 1791. Panopticon or the Inspection House. Dublin printed; London, Reprinted and sold by T. Payne.

Berch, Bettina. 2009. From Hester Street To Hollywood: The Life and Work of Anzia Yezierska. New York: Sefer International.

Billeter, Irene. 2011. New York City: "Gilt Cage" Or "Promised Land"? Representations of Urban Space in Edith Wharton and Anzia Yezierska. Bern: Lang.

Burstein, Janet H. 1996. Writing Mothers, Writing Daughters: Tracing the Maternal in Stories by American Jewish Women. Urbana and Chicago: Illinois University Press.

Clarke, Edward H. (1873) 2014. Sex in Education or a Fair Chance for Girls. CreateSpace Independent Publishing Platform. From Boston: J. Osgood \& Co.

Davidman, Lynn and Shelly Tenenbaum, eds. 1994. Feminist Perspectives on Jewish Studies. New Haven, CT: Yale University Press.

Ewen, Elizabeth. 1985. Immigrant Women in the Land of Dollars: Life and Culture on the Lower East Side 1890-1925. New York: New York University Press. 
Foucault, Michel. 1977. Discipline and Punish: the birth of the prison. Translated by Alan Sheridan. London: Penguin Books.

Ginsberg, Alan R. 2016. Salome Ensemble: Rose Pastor Stokes, Anzia Yezierska, Sonya Levien and Jetta Goudal. New Yok: Syracuse University Press.

Glenn, Susan A. 1990. Daughters of the Shtetl: Life and Labor in the Immigrant Generation. Ithaca and London: Cornell University Press.

Hoy, Suellen. 1995. Chasing Dirt: The American Pursuit of Cleanliness. New York: Oxford University Press.

Kelley, Thomas. 2005. "Rediscovering Vulgar Charity: A Historical Analysis of America's Tangled Nonprofit Law”. Fordham Law Review 73 (6): 2437-2499.

Kerber, Linda K., Alice Kessler-Harris and Kathryn Kish Sklar, eds. 1995. U.S. History as Women's History: New Feminist Essays. Chapel Hill \& London: North Carolina University Press.

Konzett, Delia C. 1997. "Administered Identities and Linguistic Assimilation: The Politics of Immigrant English in Anzia Yezierska's Hungry Hearts". American Literature, 69 (3, September). Duke University Press: 595-619.

Leavitt, J. W. 1995. "Gendered Expectations: Women and early twentieth-century Public Health". In U.S. History as Women's History: New Feminist Essays, edited by Linda K. Kerber, Alice Kessler-Harris and Kathryn Kish Sklar. Chapel Hill \& London: North Carolina University Press.

Merish, L. 2012. "The Matter of Identification: Yezierska's Arrogant Beggar and the gendered Injuries of Class". Studies in American Fiction 39 (2, Fall). The John Hopkins University Press: 207-241.

Payant, K. and Toby Rose, eds. 1999. The immigrant experience in North American literature: Carving out a niche. Westport, CT: Greenwood Press.

Pimpare, S. 2004. The New Victorians: Poverty, Politics, and Propaganda in Two Gilded Ages. New York: The New Press.

Stubbs, Katherine. 1998. "Reading Material: Contextualizing Clothing in the Work of Anzia Yezierska". MELUS: Multi-Ethnic Literature of the U.S. 23, (2, Summer) Oxford University Press: 157-172.

Yezierska, Anzia. 2003 (1925). Bread Givers. New York: Persea Books.

Yezierska, Anzia. 2004 (1927). Arrogant Beggar. Durham and London: Duke University Press.

Yezierska, Anzia. 2010 (1920). Hungry Hearts. Lexington, KY: Forgotten Books.

Yezierska, Anzia. 2010 (1920). "The Free Vacation House”. In Hungry Hearts.

Yezierska, Anzia. 2010 (1920). "My Own People”. In Hungry Hearts. 